\title{
Statsbibliotekets Open Journal Systems server: Fra 5 til 55 tidsskrifter på 8 år
}

\section{Af Jesper Boserup Thestrup og Niels Erik Frederiksen}

Statsbibliotekets og AU Library's tilbud om at udgive tidsskifter for redaktioner med til knytning til Aarhus Universitet eller Kulturministeriet har siden starten i 2008 gennemgået en voldsom udvikling. I denne artikel vil vi kort redegøre for de overordnede træk i udviklingen samt tidsskifternes forhold til Open Access og Den Bibliometriske Forskningsindikator. Tjenesten er baseret på en Open Journal Systems server (OJSserver). ${ }^{1}$

\section{1: Udviklingen i brugen af serveren:}

OJS-serveren tilgængeligg $\varnothing r$ i dag 58 tidsskifter. 55 af disse har enten tilknytning til Aarhus Universitet eller Kulturministeriets område. De tre sidste er tilknyttede Aalborg Universitet og udgives samtidigt på deres OJS-server. De vil senere blive slettet fra vores server. Interessen for serveren har været stigende siden 2008. I 2008 kunne brugerne tilgå 5 tidsskifter. Siden da er der kommet omkring 7 tidsskrifter til per år. I første halvår af 2015 er der blevet udgivet yderligere 10 tidsskifter på serveren og det forventes at der er yderligere 2 på vej i 2 . halvdel. 16 af de 58 tidsskifter udkom for første gang på serveren og var således helt nye tidsskrifter.

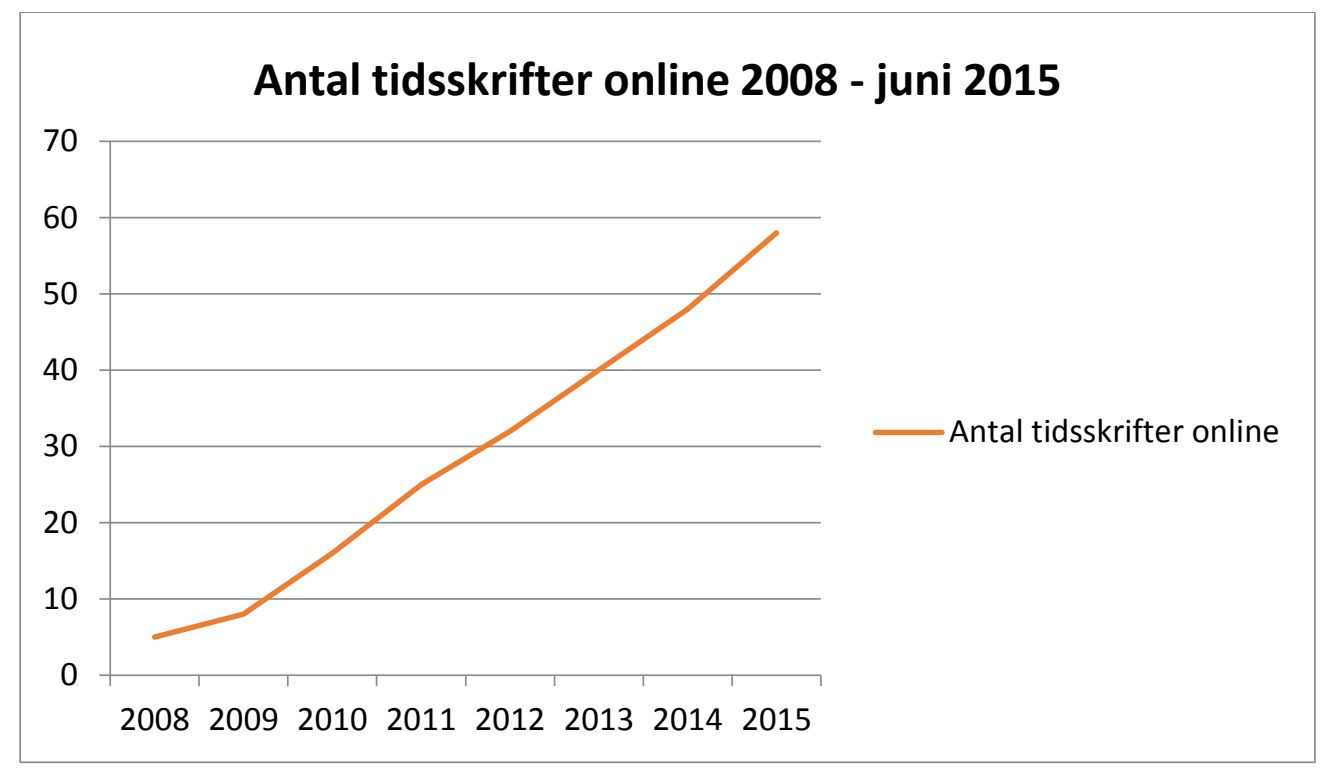

Figur 1: Antal tidsskrifter på OJS-server 2008 - juni 2015

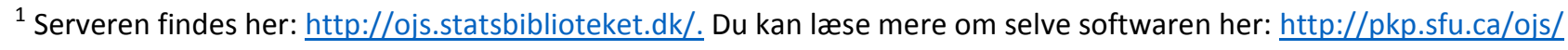


Antallet af udgivne artikler er naturligvis vokset på grund af den store stigning i antallet af tidsskifter. I 2008 var der over 1.100 artikler tilgængelige og i december 2014 var det muligt at læse over 6.800 artikler.

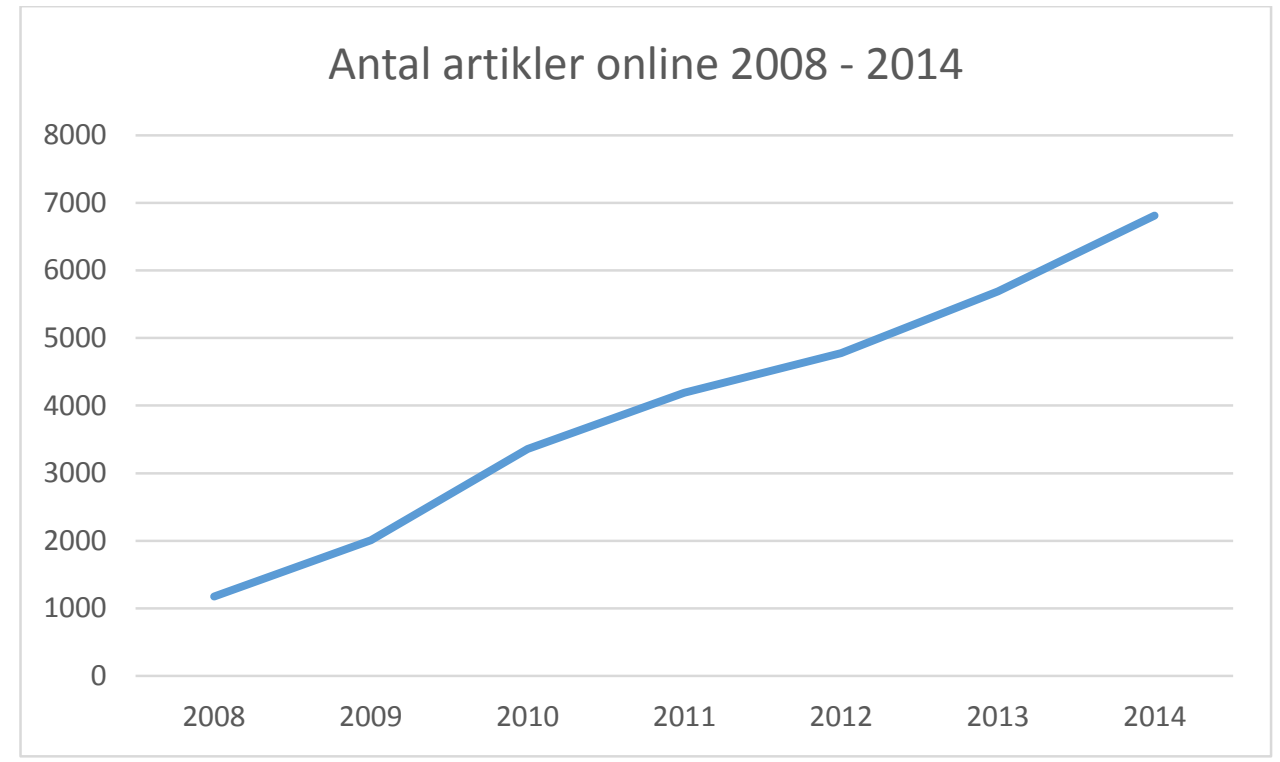

Figur 2: Antal artikler online 2008 - 2014

De offentliggjorte artikler bliver brugt. Antallet af visninger og downloads har været kraftigt stigende. Samlet set er brugen steget fra 15.000 downloads og visninger i 2008 til 934.000 i 2014 . Vi fors $\emptyset$ ger at sikre, at diverse søgemaskiner og bots ikke indgår i disse opgørelser, men det er umuligt helt at undgå disse.

Brugsdata følger tydeligt studieåret og ny udgivelser. Det vil sige at brugen falder i ferierne og stiger når der udgives nye numre. Selv tidsskifter, der er gået ind læses.

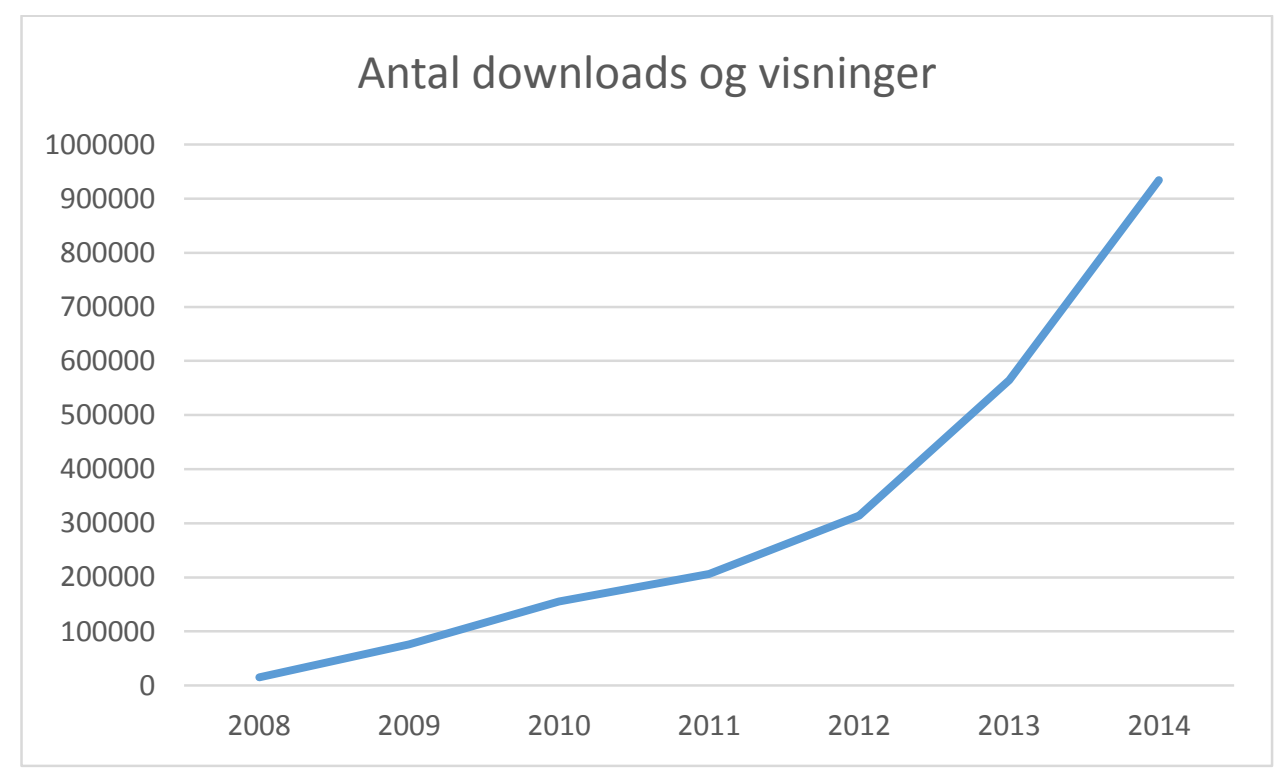

Figur 3: Antal Downloads og visninger 


\section{2: Den faglige fordeling af tidsskrifterne:}

Tidsskifterne fordeler sig på alle fakulteter, men har en overvægt på humaniora og samfundsvidenskab. Det skyldes ikke at vi bevidst fravælger ST og Health, men interessen har været størst fra ARTS og BSS.

Samtidigt er det vores fornemmelse, at der på ST og Health ikke er så mange tidsskifter baseret i Danmark som i de to andre områder.

\begin{tabular}{|l|l|l|l|l|}
\hline Fakultet* & ARTS & BSS & ST & HEALTH \\
\hline Antal tidsskifter & 28 & 17 & 10 & 2 \\
\hline
\end{tabular}

Tabel 1: Fordeling af tidsskifter per fakultet

*Tidsskifterne er fordelt på fakulteterne som Aarhus Universitet definerer dem. Det gælder også de tidsskifter, der ikke er fra Aarhus Universitet. Et enkelt falder dog helt uden disse kategorier og er ikke medtaget i optællingen. Det drejer sig om vores eget 'OJS på dansk', der er etableret som en service for alle vore OJS-redaktioner.

\section{3: Open Access}

Alle tidsskifterne på nær ét er baseret på Open Access. Det ene tidsskrift indeholder konference papirer, der kun er tilgængelige for den pågældende konferences deltagere. Fremover vil alle tidsskifter skulle give Open Acces enten umiddelbart eller efter en embargoperiode. I øjeblikket tilbyder 41 tidsskifter umiddelbar Open Access, mens 17 først giver adgang efter en vis periode. Tendensen er at helt nye tidsskrifter udgives med Open Access og at de fleste tidsskrifter har en embargoperiode på maksimalt et år. Redaktionerne for nye tidsskifter fortæller eksplicit, at de ønsker at leve op til de krav, der stilles $\mathrm{i}$ forbindelse med Danmarks Nationale Strategi for Open Access².

\begin{tabular}{|l|c|c|c|c|}
\hline $\begin{array}{l}\text { Open Access } \\
\text { fordelt efter } \\
\text { embargoperiode }\end{array}$ & $\begin{array}{l}\text { Umiddelbar Open } \\
\text { Access }\end{array}$ & Efter et år & Efter to til fem år & Ingen adgang \\
\hline Antal tidsskrifter & 41 & 11 & 5 & 1 \\
\hline
\end{tabular}

Tabel 2: Open Access

Open Access afspejler sig ikke nødvendigvis i brugen af tidsskifterne. Det mest bes $\varnothing$ gte tidsskrift giver umiddelbar Open Access, hvorimod det næstmest og trediveres brugte tidsskrift har en embargoperiode på henholdsvis 1 år og 5 år. Der er i alle tre tilfælde tale om tre tidsskifter, der har kunne trække brugere til via diverse abonnementsordninger. Umiddelbart virker det til at renommé og faglighed er mere afgørende. For de helt nye tidsskifter synes Open Access at have været en nødvendighed for at kunne tiltrække læsere.

${ }^{2}$ http://ufm.dk/aktuelt/pressemeddelelser/2014/alle-skal-have-gratis-adgang-til-forskningsresultater 


\section{4: OJS-serveren og Den Bibliometriske Forskningsindikator}

AU Library og Statsbibliotekets OJS-server udgiver en række tidsskifter, der er registeret på Uddannelsesog Forskningsministeriets liste over tidsskifter, der giver points - jævnfør Den Bibliometriske Forskningsindikator $(\mathrm{BFI})^{3}$.

Ud af de 58 tidsskrifter som OJS-serveren giver adgang til er de 34 nævnt på BFI-listen. Ud af de 55 tidsskrifter, der er tilknyttet Aarhus Universitet eller Kulturministeriets område giver $31 \mathrm{BFI}$ points. 28 giver et point og 3 giver to points.

Blandt de resterende tidsskifter er der en del, der ikke kan give points. Det skyldes, at der enten ikke er tale om videnskabelige tidsskrifter, eller at tidsskrifterne er gået ind. Endelig kan der være tale om tidsskifter, der er så nye, at de endnu ikke har kunnet opnå point. Vi håber naturligvis, at der løbende kommer flere tidsskrifter på serveren, der giver BFI Points.

\section{5: Status over udviklingen}

Som det fremgår af ovenstående har OJS-serven været kraftig vækst. En vækst vi formoder vil fortsætte i årene fremover da vi kontakt til en række redaktioner og institutioner, der gerne vil udkomme på serveren. I forhold til Open Access forventer vi at umiddelbar Open Access eller Open Acces med en relativt kort embargo på et år eller derunder vil forsætte med at være normen for tidsskrifterne på serveren.

Vi håber naturligvis at stadigt flere tidsskifter på serveren kommer på listen over tidsskifter der giver forfatteren et eller flere BFI-point. Vi har dog ingen forventning om at alle tidskrifter kan komme på listen.

I 2015 startede vi en tjeneste, hvor ansatte fra Aarhus Universitet kan udgive e-bøger. En såkaldt OMP-server ${ }^{4}$. Vi håber at vores erfaringer på tidsskriftsområdet kan være med til at sikre forskere fra Aarhus Universitet en god mulighed for at få udgivet litteratur, som måske ellers ikke ville være blevet publiceret, og derved yderligere være med til synliggøre forskningen.

\footnotetext{
${ }^{3}$ http://ufm.dk/forskning-og-innovation/statistik-og-analyser/den-bibliometriske-forskningsindikator?searchterm=BFI ${ }^{4}$ http://ebooks.au.dk/index.php/aul
} 